\title{
Ovarian Cancer Pathologic TNM Finding v6
}

National Cancer Institute

\section{Source}

National Cancer Institute. Ovarian Cancer Pathologic TNM Finding v6. NCI Thesaurus. Code C60888.

A pathologic finding about one or more characteristics of ovarian cancer, following the rules of the TNM AJCC v6 classification system. 